\title{
De Zelf-Determinatie Theorie: kwalitatief goed motiveren op de werkvloer ${ }^{1}$
}

\author{
Anja Van den Broeck, Maarten Vansteenkiste, Hans De Witte, Willy Lens en \\ Maarten Andriessen*
}

De oproep voor een positievere oriëntatie in de arbeids- en gezondheidspsychologie heeft het afgelopen decennium onderzoek gestimuleerd naar optimaal functioneren van werknemers. De Zelf-Determinatie Theorie (ZDT) kan deze positieve benadering theoretisch helpen onderbouwen en een coherente uitbouw van het domein helpen realiseren. Deze theorie gaat immers uit van een positief mensbeeld en behandelt op basis hiervan de regulatie en doelgerichtheid van het menselijke gedrag en de belangrijke basisbehoeften. In deze bijdrage wordt de ZDT en haar relaties met andere arbeids- en organisatietheorieën besproken. Eveneens wordt er ingegaan op de empirische evidentie voor de ZDT en haar praktische relevantie voor de werkcontext.

\section{Inleiding}

Het afgelopen decennium werd zowel in de psychologie in het algemeen (Seligman \& Chikzentmihalyi, 2000) als in de psychologie van arbeid en gezondheid (A\&Gpsychologie; Luthans \& Youssef, 2004; Schaufeli \& Bakker, 200I; Schaufeli, 2004) opgeroepen om niet langer uitsluitend te focussen op negatieve aspecten van het menselijk bestaan, maar ook aandacht te schenken aan positieve fenomenen. Aansluitend is er in de A\&G-psychologie grote aandacht ontstaan voor werkgerelateerd welbevinden (bijv. bevlogenheid en flow), krachtige eigenschappen van werknemers (bijv. hoop en optimisme) en stimulerende werkaspecten (bijv. job resources en ondersteunend leiderschap; Schaufeli, 2004). Deze toegenomen aandacht voor het welzijn is niet alleen goed voor de werknemers zelf. Ook organisaties kunnen er hun voordeel mee doen. Organisaties staan immers voortdurend voor de uitdaging om

* Anja Van den Broeck, Hans De Witte en Willy Lens zijn verbonden aan het departement Psychologie van de K.U. Leuven.

Maarten Vansteenkiste is verbonden aan de vakgroep Ontwikkelings-, Persoonlijkheids- en Sociale Psychologie van de Universiteit Gent.

Maarten Andriessen is werkzaam bij het adviesbureau Adforum.

Correspondentieadres: Anja Van den Broeck, Tiensestraat 102, bus 3725, B-3000 Leuven, tel. 0032-16325975, e-mail Anja.VandenBroeck@psy.kuleuven.be. 
het beste in hun werknemers naar boven te halen om zo een competitieve speler op de markt te kunnen zijn (Luthans \& Youssef, 2004). De motivatie van werknemers kan hierbij een cruciale rol spelen (Steers, Mowday \& Shapiro, 2004).

Hoewel verschillende motivatietheorieën de positieve benadering binnen de A\&Gpsychologie zouden kunnen ondersteunen, wordt in de literatuur en praktijk slechts een beperkt aantal motivatietheorieën gebruikt (Pinder, 2008). In dit artikel willen we aangeven dat de Zelf-Determinatie Theorie (ZDT; Deci \& Ryan, 200o; Vansteenkiste, Ryan \& Deci, 2008) een betrouwbaar theoretisch kader kan bieden voor de positieve benadering binnen de A\&G-psychologie en kan helpen om de kennis binnen dit domein op een coherente wijze te vergroten (Deci \& Vansteenkiste, 2004).

De ZDT is de afgelopen veertig jaar op basis van wetenschappelijk onderzoek ontwikkeld en toegepast in talrijke levensdomeinen zoals onderwijs, sport, relaties en opvoeding. Recent is deze theorie ook geïntroduceerd in de arbeidscontext (Gagné \& Deci, 2005; Sheldon, Turban, Brown, Barrick \& Judge, 2003) en is haar bruikbaarheid empirisch aangetoond (zie Van den Broeck, Vansteenkiste \& De Witte, 2008, voor een overzicht).

In deze bijdrage willen we aangeven hoe de ZDT het onderzoek en de praktijk van werkmotivatie kan bevorderen. In de eerste plaats komen de basisveronderstellingen van de ZDT aan bod. Daarna bespreken we de centrale concepten: de psychologische basisbehoeften, gedragsregulaties en doeloriëntaties. Voor lezers die meer vertrouwd zijn met andere positief georiënteerde begrippen en theorieën binnen de A\&Gpsychologie, stippen we enkele gelijkenissen en verschillen aan tussen deze theorieën en de concepten van de ZDT. We gaan ook telkens in op empirisch onderzoek waaruit de relevantie van de ZDT-concepten voor de werkcontext blijkt. Tot slot formuleren we enkele aanbevelingen naar de praktijk. Samengevat, willen we in dit artikel aantonen dat de ZDT een omvattende theorie is, die inzicht kan geven in optimaal motiverende persoonseigenschappen en organisatieaspecten en kan helpen om werknemers optimaal te laten functioneren op het werk, in termen van welzijn, positieve attitudes en gedrag (zie figuur I).

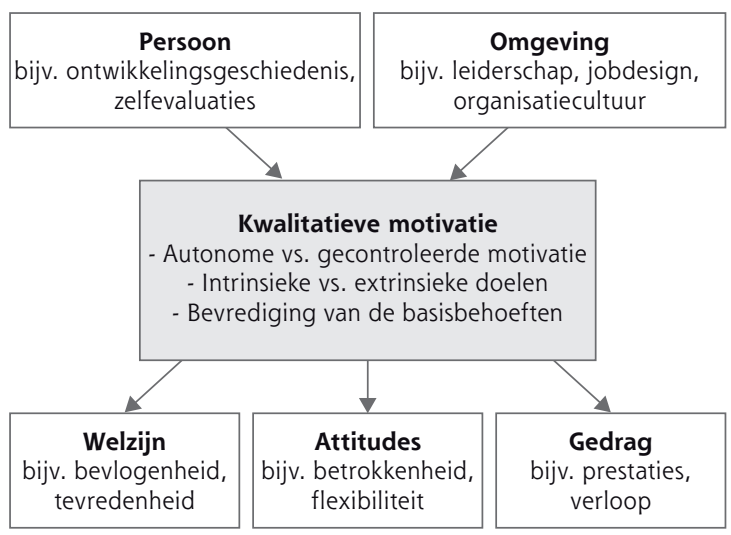

Figuur 1 Zelf-Determinatie Theorie: Een macrotheorie van menselijke motivatie (aanpassing van Gagné $\&$ Deci, 2005) 


\section{De basisveronderstellingen van de ZDT}

De ZDT neemt een bijzondere plaats in binnen de motivatiepsychologie. Zij vertrekt immers vanuit een positief mensbeeld (Sheldon et al., 2003). In dit mensbeeld wordt verondersteld dat mensen niet re-actief zijn, maar van nature pro-actief hun omgeving vormgeven (Deci \& Vansteenkiste, 2004). Anders dan bijvoorbeeld de Goal Setting Theory (Latham \& Locke, 2006; Locke \& Latham, I990) of de Expectancy-Value Theories (Feather, I992; Vroom, I964), neemt de ZDT hierbij expliciet aan dat deze activiteit gericht is op groei en integratie. Mensen evolueren tijdens hun leven naar een meer geïntegreerd en authentiek functioneren, zowel op individueel als sociaal niveau.

De aangeboren actieve groeitendens komt volgens de ZDT echter niet onvoorwaardelijk tot uiting. Ze manifesteert zich alleen wanneer mensen in een stimulerende omgeving vertoeven. Werknemers zullen alleen optimaal functioneren wanneer ze

318 door hun werk uitgedaagd worden en ze de ruimte krijgen om zich met boeiende activiteiten bezig te houden. Als werknemers geconfronteerd worden met een chaotische of controlerende omgeving, zal hun groei(tendens) geblokkeerd worden en zullen ze zich gefrustreerd voelen. Ze lopen dan het risico gedemotiveerd en contraproductief te worden.

Het positieve, humanistische mensbeeld van de ZDT staat haaks op de veronderstellingen binnen vele andere A\&G-theorieën. De Regulatory Focus Theory (Higgins, I997; 2000) en de Conservation of Resources Theory (Hobfoll, I989; 2002) stellen bijvoorbeeld dat werknemers vooral erop uit zijn om onplezierige situaties te vermijden en plezierige situaties te maximaliseren. Analoog gaan de Theory X van McGregor (1960) en de Agency Theory (Shapiro, 2005) ervan uit dat werknemers inherent lui zijn en om deze reden sterk gedirigeerd en gecontroleerd moeten worden opdat ze zich zouden inzetten. De ZDT sluit echter wel aan bij Theorie Y van McGregor. Beide theorieën stellen dat werknemers graag werken, hun talenten willen ontwikkelen en verantwoordelijkheden op zich willen nemen als ze daartoe gestimuleerd worden.

McGregor plaatste Theorie $\mathrm{Y}$ als een evenwaardig alternatief naast Theory $\mathrm{X}$ en beschreef de gevolgen van elk van deze theorieën voor werkgevers en werknemers. De ZDT trekt daarentegen duidelijk de kaart van het positieve mensbeeld en postuleert dat dit de ware aard van mensen weerspiegelt. Vanuit deze achtergrond wordt het evident om ook aandacht te besteden aan positieve fenomenen en optimaal functioneren. Daarom kan het uitgangspunt van de ZDT een basis vormen van de positieve A\&G-psychologie (Deci \& Vansteenkiste, 2004).

Daarnaast kan de ZDT ook helpen om de positieve A\&G-psychologie op coherente en theoretisch gefundeerde wijze uit te bouwen en een geïntegreerd beleid te voeren in de praktijk. De ZDT is immers een omvangrijke theorie die ingaat op belangrijke menselijke behoeften, doeloriëntaties en gedragsregulaties. Ze gaat dus zowel over 'wat' mensen nastreven (d.w.z. doeloriëntaties) als over 'waarom' ze dat doen (d.w.z. gedragsregulaties) binnen hetzelfde theoretische kader. Waar andere theorieën vooral kijken naar hoe sterk werknemers gemotiveerd zijn (d.w.z. kwantitatieve benadering), legt de ZDT de nadruk op hoe goed deze motivatie is (d.w.z. kwalitatieve benadering; Vansteenkiste, Lens \& Deci, 2006). 
De aandacht voor het onderliggende mechanisme van motivatie (d.w.z. de bevrediging van de drie aangeboren psychologische behoeften aan autonomie, competentie en relationele verbondenheid) laat bovendien toe motivatie van werknemers ten volle te begrijpen en in te spelen op onderliggende processen in plaats van louter op de uitkomsten. In de volgende paragrafen worden de basisbehoeften, gedragsregulaties en doeloriëntaties zoals deze in de ZDT worden gedefinieerd, toegelicht.

\section{Psychologische basisbehoeften: de motor van optimaal functioneren}

De ZDT beschouwt de bevrediging van de aangeboren psychologische basisbehoeften aan autonomie ('autonomy'), verbondenheid ('belongingness') en competentie ('competence') als cruciale voedingsstoffen voor persoonlijke ontwikkeling en optimaal functioneren (Deci \& Ryan, 2000; Reeve, 2005).

De behoefte aan relationele verbondenheid wordt gedefinieerd als de wens om positieve relaties op te bouwen met anderen, zich geliefd en verzorgd te voelen en zelf voor anderen te zorgen (Baumeister \& Leary, 1995; Deci \& Ryan, 2000). Werknemers kunnen zich verbonden voelen wanneer ze deel uitmaken van een hecht team en hun persoonlijke gevoelens en gedachten kunnen delen met collega's. Het belang van sociale relaties wordt in de A\&G-psychologie al lang erkend. Jahoda (I982) bijvoorbeeld, beschouwde sociale contacten als een belangrijke latente functie van arbeid. Verder wordt er binnen de A\&G-psychologie ook aandacht geschonken aan concepten als eenzaamheid op het werk (bijv. Wright, Burt \& Strongman, 2006), sociale steun (bijv. Viswesvaran, Sanchez \& Fisher, 1999) en teamwerk (bijv. LePine, Piccolo, Jackson, Mathieu \& Saul, 2008). In het algemeen staat de behoefte aan sociaal contact hierbij centraal. De ZDT gaat een stapje verder en benadrukt dat dergelijk sociaal contact betekenisvol en diepgaand moet zijn, opdat werknemers zich echt verbonden zouden voelen (Reis, Sheldon, Gable, Roscoe \& Ryan, 2000).

De behoefte aan competentie is de wens om doeltreffend met de omgeving om te gaan (Deci \& Ryan, 2000; White, I959). Mensen willen hun omgeving exploreren, begrijpen en beheersen. Het gevoel van competentie helpt werknemers zich te ontwikkelen en verhoogt hun capaciteit om zich flexibel aan te passen aan veranderende omgevingen. Vele A\&G-perspectieven beklemtonen dat het belangrijk is dat werknemers zich bekwaam voelen. De Expectancy-Value Theories en Self-Efficacy Theory (Bandura, I997), bijvoorbeeld, beschouwen de subjectieve verwachting om taken succesvol uit te kunnen voeren als een belangrijke motivator. Deze theorieën leggen hierbij de nadruk op de aangeleerde verwachtingen om een specifieke taak tot een goed einde te brengen. In de ZDT verwijst competentie naar een aangeboren behoefte. Wie zich competent voelt, zal daarom niet alleen met meer zelfvertrouwen zijn werk aanpakken, maar ook beter in zijn vel zitten (Deci \& Ryan, 200o; White, 1959). ZDT's competentie-behoefte sluit daarmee aan bij de perceptie van persoonlijke effectiviteit zoals omschreven in de Goal-Setting Theory. Ook deze laatste theorie schenkt immers aandacht aan het gevoel effectief te zijn, dat ontstaat nadat men een doel bereikt heeft. Net zoals in de ZDT, beantwoordt dit gevoel volgens de Goal-Setting 
Theory aan een universele psychologische behoefte en leidt het tot meer welzijn (Latham \& Locke, 2006).

De behoefte aan autonomie, tot slot, verwijst naar de wens om psychologisch vrij te kunnen handelen en niet onder druk te staan (DeCharms, ı968; Deci, r971). Het concept autonomie kent een lange geschiedenis binnen de A\&G-psychologie. 'Zelf kunnen beslissen' staat hierbij doorgaans centraal. Karasek (1979) definieerde autonomie bijvoorbeeld in termen van beslissingsruimte en controlemogelijkheden, terwijl Hackman en Oldham (I976) autonomie gelijkstelden met persoonlijke vrijheid en onafhankelijkheid. Belangrijker dan alles zelf te kunnen aansturen, is volgens de ZDT echter het gevoel zonder druk te kunnen functioneren. Dit gevoel van psychologische vrijheid kan tot stand komen wanneer werknemers de kans krijgen om zelf (mee) te beslissen of wanneer zij keuzemogelijkheden krijgen. Het kan echter ook ontstaan wanneer taken op empathische wijze en met voldoende verantwoording worden

320 opgedragen. Volgens de ZDT is de behoefte aan autonomie dus bevredigd wanneer werknemers volledig achter (de reden voor) hun gedrag staan, ongeacht of ze dit gedrag zelf geïnitieerd hebben, zoals in het geval van keuze en beslissingsrecht, of dat ze hiertoe werden aangezet door de omgeving die het gedrag als betekenisvol duidde. Dit komt overeen met de stelling in de Goal Setting Theory dat doelen meer motiverend zijn als men ze zelf heeft geformuleerd en, als het gaat om door anderen opgelegde doelen, men deze als zinvol beschouwt.

Dat 'behoeften' centrale elementen zouden zijn voor de motivatie van werknemers, is niet nieuw. Maslow (I943) postuleerde bijvoorbeeld een hiërarchisch behoeftemodel waarin lagere deficiëntiebehoeften, zoals voeding en fysieke veiligheid, in voldoende mate moesten worden bevredigd alvorens groeibehoeften, zoals liefde en zelfrealisatie, tot uiting konden komen. McClelland (1965) onderzocht onder andere de prestatiebehoefte en de behoefte aan macht, die essentieel worden geacht voor goede leidinggevenden. Hackman en Oldham benadrukten het belang van de behoefte aan groei opdat jobverrijking het functioneren van werknemers zou bevorderen. Higgins (2000), tot slot, stelde dat mensen ofwel handelen vanuit een groeibehoefte, ofwel vanuit een behoefte aan veiligheid.

Het ZDT-concept van aangeboren basisbehoeften verschilt echter van deze visies. Voorgaande benaderingen besteden immers vooral aandacht aan behoeften die ontstaan naarmate mensen zich ontwikkelen. Omdat iedereen andere levenservaringen heeft, verschilt het belang van de verschillende behoeften per individu, wat implicaties heeft voor het functioneren. Zo zullen bijvoorbeeld enkel werknemers die herhaaldelijk geprezen worden voor het behalen van een bepaald doel of prestatieniveau, een sterkere prestatiebehoefte (Winterbottom, I959) of promotie-oriëntatie (Higgins, 2000) ontwikkelen. Volgens McClelland bepaalt de sterkte van de prestatiebehoefte vervolgens de mate waarin iemand gemotiveerd is in competitieve situaties. Analoog daaraan zetten promotiegeoriënteerde werknemers zich volgens Higgins meer in dan preventiegeoriënteerde werknemers wanneer doelen worden geformuleerd in termen van succes. Tot slot profiteren volgens Hackman en Oldham werknemers die een sterke groeibehoefte ontwikkeld hebben, meer van verrijking van het werk dan hun collega's die minder gericht zijn op groei.

In tegenstelling tot voorgaande kaders stelt de ZDT dat de drie basisbehoeften ingebakken zitten in de menselijke natuur. Het betreft daarom in de ZDT geen verschil- 
len tussen mensen in de sterkte van deze behoeften, maar wel verschillen in de mate waarin mensen hun behoeften hebben bevredigd. Deze focus is analoog aan de vaak gehanteerde zienswijze op fysieke behoeften: hoewel mensen kunnen verschillen in de mate waarin ze honger hebben, is de mate waarin ze op een gegeven moment hun honger hebben kunnen stillen van cruciaal belang voor hun fysieke functioneren (Deci \& Ryan, 2000). Omdat de ZDT ervan uitgaat dat iedereen de drie basisbehoeften heeft en dat iedereen profiteert van de bevrediging ervan, wordt gesteld dat omgevingsfactoren die de behoeften voeden voor iedereen motiverend zijn. Iedereen zal volgens de ZDT dus profiteren van positief gepercipieerde feedback, zelfs werknemers die het niet belangrijk vinden om de specifieke taak goed uit te voeren (Mouratidis, Vansteenkiste, Lens \& Sideris, 2008). Verder onderzoek zou beide visies op behoeften kunnen contrasteren en bijvoorbeeld kunnen nagaan of de bevrediging van de aangeboren behoefte aan relationele verbondenheid leidt tot positieve gevolgen voor mensen met een sterke, aangeleerde behoefte aan affiliatie.

In het algemeen kan vanuit de Conservation of Resources Theory de bevrediging van de psychologische basisbehoeften worden gezien als een belangrijke persoonlijke hulpbron die de accumulatie van andere hulpbronnen stimuleert. De idee van essentiële universele basisbehoeften sluit eveneens aan bij de behoeften aan zelfbehoud en zelfactualisatie van Herzberg (I968) en de kritische psychologische toestanden (d.w.z. betekenis, verantwoordelijkheid en kennis) van Hackman en Oldham. Ook Herzberg ging er namelijk van uit dat iedereen de behoeften aan zelfbehoud en zelfactualisatie bezit. Hackman en Oldham zagen tevens de vervulling van de psychologische toestanden als een cruciale voorwaarde voor optimaal functioneren.

Terwijl empirische evidentie voor deze laatste behoefte-concepten schaars is (Pinder, 2008), worden de behoeften van de ZDT uitgebreid empirisch ondersteund. Talrijke studies hebben immers aangetoond dat werknemers die zich autonoom, competent en verbonden voelen, beter functioneren dan hun collega's van wie de behoeften niet voldoende bevredigd zijn. De eerstgenoemden zijn meer tevreden met hun werk (Ilardi, Leone, Kasser \& Ryan, I993), vitaler, minder uitgeput (Van den Broeck, Vansteenkiste, De Witte \& Lens, 2008), brengen vrijwillig meer tijd door op het werk (Gagné, 2003; Kasser, Davey \& Ryan, 1992), accepteren organisatieveranderingen makkelijker (Gagné, Koestner \& Zuckerman, 2000; Lynch, Plant \& Ryan, 2005), zijn minder geneigd om ontslag te nemen (Vansteenkiste, Neyrinck, et al., 2007) en presteren beter (Baard, Deci \& Ryan, 2004). Bovendien gaat behoeftebevrediging op het werk samen met meer welzijn buiten de werkcontext (Deci, Ryan, Gagné, Leone, Usunov et al., 200I).

Volgens de ZDT kan de werkcontext de behoeften van de werknemers sterk beïnvloeden. In lijn hiermee toonde empirisch onderzoek aan dat HRM-praktijken rechtstreeks kunnen inspelen op de bevrediging van de psychologische basisbehoeften (Gagné \& Deci, 2005). De behoeften aan autonomie, competentie en relationele verbondenheid worden bijvoorbeeld bevredigd in een algemeen ondersteunend werkklimaat (Deci et al., 200I; Gagné, 2003) en wanneer leidinggevenden empatisch zijn, keuzes bieden, informatie geven en initiatief stimuleren (Baard et al., 2004; Deci, Connell \& Ryan, I989; Gagné, 2003). De basisbehoeften worden ook bevredigd bij banen waarin ondersteunende werkkenmerken domineren (bijv. sociale steun, feedback) en veeleisende werkkenmerken afwezig zijn (bijv. emotionele belasting, werk- 
thuisinterferentie; Gagné, Senécal \& Koestner, I997; Van den Broeck, Vansteenkiste, De Witte et al., 2008). Bovendien kunnen de basisbehoeften verklaren waarom jobdesign zo'n belangrijke impact heeft op het functioneren van werknemers (Van den Broeck, Vansteenkiste, De Witte et al., 2008).

Samengevat is de bevrediging van behoeften aan autonomie, competentie en verbondenheid dus een belangrijke voorwaarde voor het optimaal functioneren van werknemers, zowel in termen van welzijn, positieve attitudes als coöperatief en productief gedrag. Behoeftebevrediging kan daarenboven een handig criterium zijn bij het vormgeven van HRM-praktijken. Wanneer HRM-praktijken tegemoetkomen aan de behoeften aan autonomie, competentie of verbondenheid, zullen ze bijdragen aan het optimaal functioneren van werknemers en het succes van de organisatie. Interventies die de behoeftebevrediging frustreren, zullen leiden tot minder positieve uitkomsten. Behoeftebevrediging biedt daarnaast ook de mogelijkheid om het 'waarom' (d.w.z. 322 gedragsregulaties) en het 'wat' (d.w.z. doeloriëntaties) van de motivatie van werknemers te begrijpen. Dit komt in volgende paragrafen aan bod.

\section{Autonome en gecontroleerde motivatie: het 'waarom" van motivatie}

Van oudsher wordt er in de motivatiepsychologie een onderscheid gemaakt tussen intrinsieke en extrinsieke motivatie (Deci, 1971). Intrinsieke motivatie verwijst naar het uitvoeren van een activiteit omdat ze op zich leuk of interessant is. Zo kan een vertegenwoordigster met plezier naar het werk gaan omdat ze dol is op het sociale contact dat het werk haar biedt. Bij extrinsieke motivatie daarentegen, wordt gedrag vertoond omwille van een uitkomst die buiten de activiteit gelegen is. Niet de inhoud van het werk, maar wel de uitkomsten van het werk vormen hierbij de belangrijkste bron van motivatie. Wie een baan aanvaardt omwille van goede (secundaire) arbeidsvoorwaarden, is bijvoorbeeld extrinsiek gemotiveerd.

De positieve impact van intrinsieke motivatie is alom bekend binnen de A\&Gpsychologie. Het concept kwam onder andere aan bod bij Herzberg en werd later uitgewerkt door Hackman en Oldham. De laatstgenoemden probeerden inherent boeiende of intrinsiek motiverende banen te creëren door ze te verrijken met onder andere feedback en variatie. Veel banen bevatten echter ook taken die niet intrinsiek boeiend of leuk (kunnen) zijn, en die dus enkel uitgevoerd kunnen worden op basis van extrinsieke motieven (Sheldon et al., 2003).

Volgens verschillende motivatietheorieën (bijv. de Expectancy-Value Theory) zijn intrinsieke en extrinsieke motivatie gelijkwaardig en kunnen ze worden opgeteld om de sterkte van iemands totale motivatie te berekenen. In deze visie kan een weinig intrinsiek gemotiveerde werknemer gestimuleerd worden door een bonus, opslag of promotie te beloven of door een deadline of strikte controle in het vooruitzicht te stellen.

Eerder onderzoek binnen de ZDT toont echter aan dat extrinsieke en intrinsieke motivatie niet zonder meer opgeteld mogen worden (Deci, Koestner \& Ryan, I999). Wanneer intrinsiek gemotiveerde werknemers beloond worden, kunnen ze het gevoel krijgen dat hun eigen gevoelens van plezier en interesse niet langer aan de basis liggen 
van hun gedrag, maar dat de beloningen hun gedrag bepalen. $\mathrm{Zij}$ worden dus gefrustreerd in hun autonomie, waardoor het plezier in en de interesse voor de taak vermindert. Anderzijds kunnen beloningen ook feedback bevatten en daarmee tegemoet komen aan de behoefte aan competentie. In dat geval verhogen ze de intrinsieke motivatie (Deci et al., I999; Luyten \& Lens, 198I). De aard van beloningen en de manier waarop ze worden toegekend, bepalen dus of beloningen intrinsieke werkmotivatie versterken of ondergraven. In dit licht bestuderen zowel psychologen, economen als managementgeoriënteerde onderzoekers momenteel de grenzen van uiteenlopende beloningssystemen (Gagné \& Forest, 2008; Frey \& Osterloh, 2005; Rynes, Gerhart \& Parks, 2005). Dergelijk onderzoek leert hoe men werknemers op een goede wijze kan belonen zonder hun intrinsieke motivatie te ondermijnen.

De ZDT plaatst niet alleen vraagtekens bij de eenvoudige opstelsom van intrinsieke en extrinsieke motivatie. Ze overstijgt ook de dichotomie tussen deze concepten (Sheldon et al., 2003). De ZDT onderscheidt immers verschillende typen van extrinsieke motivatie en stelt dat deze een kwalitatief verschillende impact hebben op het functioneren van werknemers (Ryan \& Connell, I989). De typen extrinsieke motivatie situeren zich op een continuüm van kwalitatief inferieure naar hoogstaande motivatie (zie figuur 2). Deze verschillen in kwaliteit hangen samen met de mate waarin extrinsiek gemotiveerd gedrag autonoom dan wel gecontroleerd gereguleerd is. De typen gedragsregulatie zijn echter geen fasen die chronologisch doorlopen worden (Gagné \& Deci, 2005). Gedrag is immers vaak meervoudig gedetermineerd en werknemers kunnen hun taken op ieder ogenblik omwille van uiteenlopende redenen uitvoeren.

\begin{tabular}{|c|c|c|c|c|}
\hline \multicolumn{4}{|c|}{ Extrinsieke motivatie } & Intrinsieke motivatie \\
\hline $\begin{array}{l}\text { Externe } \\
\text { regulatie }\end{array}$ & $\begin{array}{l}\text { Geïntrojecteerde } \\
\text { regulatie }\end{array}$ & $\begin{array}{l}\text { Geïdentificeerde } \\
\text { regulatie }\end{array}$ & $\begin{array}{l}\text { Geïntegreerde } \\
\text { regulatie }\end{array}$ & $\begin{array}{l}\text { Intrinsieke } \\
\text { motivatie }\end{array}$ \\
\hline $\begin{array}{l}\text { Externe beloningen, } \\
\text { straffen en } \\
\text { verwachtingen } \\
\text { bv. bonus, ontslag }\end{array}$ & $\begin{array}{l}\text { Interne beloningen, } \\
\text { straffen en } \\
\text { verwachtingen } \\
\text { bv. schuld, angst, trots }\end{array}$ & $\begin{array}{l}\text { De activiteit is } \\
\text { persoonlijk } \\
\text { belangrijk of } \\
\text { waardevol }\end{array}$ & $\begin{array}{l}\text { Het belang van de } \\
\text { activiteit is een } \\
\text { integraal deel van het } \\
\text { eigen waardenpatroon }\end{array}$ & $\begin{array}{l}\text { De activiteit is } \\
\text { op zich leuk of } \\
\text { interessant }\end{array}$ \\
\hline \multicolumn{2}{|c|}{ Gecontroleerde motivatie } & \multicolumn{3}{|c|}{ Autonome motivatie } \\
\hline
\end{tabular}

Figuur 2 Het zelfdeterminatiecontinuüm gaande van gecontroleerde tot autonome motivatie (aanpassing van Ryan \& Deci, 2000)

In de eerste plaats kan het uitvoeren van bepaalde taken extern gereguleerd zijn. Deze vorm van extrinsieke motivatie omvat het uitvoeren van een activiteit om beloningen te krijgen of straffen te vermijden. Extern gereguleerde werknemers kunnen zowel promotie- als preventiegeoriënteerd zijn en zich respectievelijk inzetten om een bonus op te strijken of te vermijden dat ze ontslagen worden (materiële beloningen), of hun best doen om waardering te krijgen of kritiek te vermijden (sociale beloningen). 
Externe gedragsregulatie is uitvoerig bestudeerd binnen het behaviorisme (Skinner, I974). Het staat ook centraal in de Theory X van McGregor en de Agency-Theory. In deze theorieën wordt immers gesteld dat werknemers enkel gemotiveerd kunnen worden om zich in te zetten voor het belang van het bedrijf, wanneer ze hier zelf hun (financieel) voordeel mee doen.

De tweede vorm van extrinsieke motivatie binnen de ZDT is geïntrojecteerde regulatie. Bij geïntrojecteerde regulatie koppelen werknemers hun eigenwaarde aan het uitvoeren van een bepaalde activiteit. Ze willen negatieve gevoelens, zoals schaamte, schuld of angst, vermijden (preventie-focus) of juist positieve gevoelens, zoals trots, ervaren (promotie-focus; Assor, Vansteenkiste \& Kaplan, 2009). Terwijl extern aangevoerde factoren gedrag stimuleren bij externe regulatie, vormen intern controlerende factoren de drijfveer bij geïntrojecteerde regulatie. Werknemers zetten dus zichzelf onder druk. Omdat zowel externe als geïntrojecteerde regulatie gepaard gaan 324 met gevoelens van druk, verplichting en controle, worden ze door de ZDT gezien als vormen van gecontroleerde motivatie (Deci \& Ryan, 2000).

Geïdentificeerde en geïntegreerde regulatie vormen respectievelijk het derde en vierde type van extrinsieke motivatie op het continuüm (Ryan \& Connell, r989). Werknemers die zich identificeren met de reden voor het stellen van een activiteit, zetten zich in omdat ze de activiteit persoonlijk belangrijk of zinvol vinden. Identificatie sluit aan bij Hackman's en Oldham's definitie van gepercipieerde betekenisvolheid van het werk als kritische psychologische toestand. Het onderschrijft ook het belang van taaksignificantie en takidentiteit als motiverende taakkenmerken. Bij het vierde type van extrinsieke motivatie, geïntegreerde regulatie, hebben werknemers de reden voor het gedrag volledig geïntegreerd en wordt een activiteit uitgevoerd omdat ze past binnen het waardenkader van het individu.

Identificatie en integratie zijn extrinsieke vormen van motivatie; de activiteit wordt immers uitgevoerd om een uitkomst te bereiken die buiten de activiteit gelegen is. Men identificeert zich echter met de reden voor het stellen van het gedrag, of heeft die zelfs geïntegreerd in zijn waardensysteem. Men doet dus de activiteit omdat men het zelf wil en men handelt zonder enige dwang of druk te ervaren. Beide typen van regulatie worden daarom als vormen van autonome motivatie beschouwd (Deci \& Ryan, 2000). Omdat intrinsiek gemotiveerde werknemers spontaan hun werk uitvoeren omdat ze het op zich boeiend en leuk vinden, wordt intrinsieke motivatie gezien als de meest autonome vorm van motivatie. Autonome motivatie verwijst dus naar het gevoel zelf te willen handelen in plaats van gedirigeerd of gedwongen te worden. Autonome motivatie gaat samen met behoeftebevrediging en is daarom kwalitatief hoogstaande motivatie, die bijdraagt aan optimaal functioneren (Deci \& Ryan, 2000). Dat werknemers zich beter in hun vel voelen en beter presteren wanneer hun motivatie voornamelijk uit henzelf komt dan wanneer ze hun motivatie ontlenen aan controle, werd in de A\&G-psychologie al eerder onderschreven door bijvoorbeeld Herzberg en Jahoda.

Zoals reeds eerder geschreven, hanteert de ZDT, in tegenstelling tot bijvoorbeeld de Goal-Setting Theory en de Self-Efficacy Theory, geen louter kwantitatieve kijk op motivatie waarin 'meer' of een 'sterkere' motivatie als meer bevorderlijk wordt gezien. Ze stelt daarentegen, net als de Regulatory Fit Theory (Higgins, 2000) dat vooral de kwaliteit van motivatie ertoe doet (Vansteenkiste, Lens, De Witte \& Feather, 2005; 
Meyer, Becker \& Vandenberghe, 2004). De Regulatory Fit Theory maakt hierbij een kwalitatief onderscheid tussen de doelen die mensen willen bereiken: promotiegeoriënteerde werknemers willen hun idealen bereiken, terwijl preventiegeoriënteerde werknemers hun verplichtingen willen nakomen. De Zelf-Determinatie Theorie zet de soort redenen voor het vertonen van gedrag centraal: gecontroleerde motivatie wordt veroorzaakt door externe of interne druk, terwijl autonome motivatie voortkomt uit de waarden en interesses van werknemers. De Regulatory Fit Theory neemt aan dat een promotie- en preventiegeoriënteerdheid elk haar voor- en nadelen heeft en dat de fit tussen de persoonlijke oriëntatie en de omgeving belangrijk is om werknemers optimaal te kunnen laten functioneren. De ZDT stelt daarentegen dat autonome motivatie altijd kwalitatief beter is dan gecontroleerde motivatie. Anders dan gecontroleerde motivatie, gaat autonome motivatie gepaard met de bevrediging van de basisbehoeften. Meer nog, terwijl autonome motivatie optimaal functioneren stimuleert, zorgt gecontroleerde motivatie er voor dat mensen slechter in hun vel zitten en minder goed presteren. Volgens de ZDT is het daarom beter om enkel autonoom gemotiveerd te zijn, in plaats van zowel autonoom als gecontroleerd. Als gevolg hiervan wordt in onderzoek vaak gecontroleerde motivatie afgetrokken van autonome motivatie om zo een samenvattende maat voor de kwaliteit van motivatie te krijgen.

Verschillende studies bevestigden dat mensen beter functioneren naarmate ze meer autonoom en minder gecontroleerd gemotiveerd zijn. Dit gaat op voor zowel werknemers (bijv. Richer, Blanchard \& Vallerand, 2002) als werkzoekenden (Vansteenkiste, Lens et al., 2005; Vansteenkiste, Lens, DeWitte, De Witte \& Deci, 2004) en voor specifieke taken (Fernet, Sen, Guay, Marsh \& Dowson, 2008), werkdomeinen (bijv. Richer et al., 2002), en werkdoelen (Bono \& Judge, 2003). Hoe sterker werknemers autonoom (en niet gecontroleerd) gemotiveerd zijn voor hun werk, hoe beter ze zich voelen op het werk in termen van werktevredenheid, levenstevredenheid, affectieve organisatiebetrokkenheid, verminderde burnout en algemene gezondheid (zie bijv. Fernet, Guay \& Senécal, 2004; Judge, Bono, Erez \& Locke, 2005). Werknemers die sterk autonoom (en niet gecontroleerd) gemotiveerd zijn voor hun werk, presteren ook beter en willen minder van baan veranderen (Baard et al., 2004; Milette \& Gagné, 2008; Richer et al., 2002). Wie op meer autonome wijze gemotiveerd is voor het uitstippelen van een carrièrepad lijdt bovendien minder aan besluiteloosheid en procrastinatie (Guay, Senécal, Gauthier \& Fernet, 2003; Senécal \& Guay, 200I). Daarnaast lijden autonoom gemotiveerde werkzoekenden minder onder hun werkloosheid en zijn zij actiever op zoek naar werk dan hun meer gecontroleerde collega's (Vansteenkiste, Lens et al., 2004).

Deze resultaten komen ook naar voren wanneer de sterkte (d.w.z. de kwantiteit) van de motivatie in rekening wordt gebracht (Vansteenkiste, Lens et al., 2005), wat evidentie biedt voor de ZDT-stelling dat naast de kwantiteit vooral de kwaliteit van motivatie een rol speelt. Tot slot blijkt kwalitatief goede motivatie ook te fungeren als een persoonlijke hulpbron, zoals gedefinieerd in de Conservation of Resources Theory. Zo helpt een sterke autonome motivatie om de controlemogelijkheden binnen het werk, zoals gedefinieerd door Karasek, optimaal te benutten als buffer voor de eisende aspecten van het werk (Fernet et al., 2004; Parker, Jimmieson \& Amiot, in druk). 
De verschillende typen van motivatie kunnen zowel worden uitgelokt door de omgeving als hun oorsprong vinden bij de werknemers zelf. In de eerste plaats kunnen jobdesign en leiderschap kwalitatief goede motivatie stimuleren. Vooral werkkenmerken zoals variatie, betekenisvolheid van het werk en feedback, zoals gedefinieerd door Hackman en Oldham, blijken samen te gaan met autonome motivatie (Milette \& Gagné, 2008; Richer et al., 2002). Transformationeel leiderschap is eveneens positief gerelateerd aan kwalitatief hoogstaande motivatie, wellicht omdat transformationeel leidinggevenden vertrouwen tonen in de competenties van werknemers, hun groepsgevoel aansterken en aansluiting proberen te vinden met hun waarden (Bono \& Judge, 2003).

Ten tweede kunnen naast situationeel opgewekte motivatie ook persoonlijkheidskenmerken verklaren waarom werknemers autonoom dan wel gecontroleerd gemotiveerd zijn voor hun werk. De kernaspecten van zelfevaluatie (d.w.z. eigenwaarde, algemene

326 effectiviteit, interne controlelocus en emotionele stabiliteit) gaan bijvoorbeeld gepaard met een meer autonome in plaats van een gecontroleerde werkmotivatie (Judge et al., 2005). Daarnaast bestaat er ook een specieke persoonlijkheidstrek om te handelen vanuit autonome dan wel gecontroleerde redenen: terwijl sommige mensen hebben geleerd om in het algemeen (d.w.z. over allerlei situaties en contexten heen) het belang en de plezierige aspecten van hun gedrag te benadrukken, worden anderen eerder gedreven door externe of interne controles (Baard et al., 2004; Lam \& Gurland, 2008).

Samengevat onderscheidt de ZDT dus kwalitatief inferieure typen van motivatie (d.w.z. gecontroleerde) van kwalitatief hoogstaande (d.w.z. autonome) typen van motivatie. Autonome motivatie gaat hand in hand met optimaal functioneren (d.w.z. welzijn, positieve attitudes en constructief gedrag). Gecontroleerde motivatie is hier niet, of zelfs negatief aan gerelateerd. Naast verschillende typen van motivatie of gedragsregulatie, omschrijft de ZDT ook de motiverende impact van de doelen of waarden die mensen nastreven.

\section{Intrinsieke en extrinsieke doelen: het 'wat' van motivatie}

De motivationele impact van doelen - of op een abstracter niveau waarden - is algemeen bekend binnen de A\&G-psychologie. De Goal-Setting Theory gaat er bijvoorbeeld van uit dat werknemers optimaal gemotiveerd zijn wanneer ze streven naar specifieke, moeilijke doelen. Net zoals bij de verschillende typen van motivatie, stelt de ZDT echter dat niet alleen de kwantiteit, maar ook de kwaliteit telt. Niet alle typen van doelen hebben volgens de ZDT dezelfde motivationele impact. De ZDT deelt deze mening met bijvoorbeeld de Achievement Goal Theory, waarin prestatiedoelen van taakdoelen worden onderscheiden (Elliot \& McGregor, 20or). Terwijl de Achievement Goal Theory de oriëntatie tegenover prestatietaken bestudeert (leerdoelen versus prestatiedoelen), richt de ZDT zich vooral op doelen van hogere orde, die het functioneren in talrijke levensdomeinen kunnen beïnvloeden (Vansteenkiste, Matos, Lens \& Soenens, 2007). Ze stelt dat het nastreven van intrinsieke doelen bijdraagt tot optimaal functioneren, terwijl het najagen van extrinsieke doelen hier 
niet toe bijdraagt of misschien zelfs hier van afleidt (Deci \& Ryan, 2000; Kasser, 2002; Vansteenkiste, Soenens \& Duriez, 2008).

Intrinsieke werkdoelen zijn gericht op zelfontplooiing, het leveren van een bijdrage aan de samenleving en het opbouwen van goede sociale relaties. Extrinsieke doelen omvatten het nastreven van een hoge status, macht of financieel succes. Intrinsieke doelen sluiten aan bij de natuurlijke tendens om zich verder te ontwikkelen. Het nastreven ervan bevredigt dan ook de psychologische basisbehoeften en helpt mensen optimaal te functioneren en hun potentieel te realiseren (Kasser, 2002). Extrinsieke doelen leiden daarentegen af van de inherente groeitendens. Bij het nastreven van extrinsieke doelen wordt bijvoorbeeld de eigenwaarde afhankelijk van de mening van anderen, wat kan leiden tot stressvolle interpersoonlijke vergelijkingen (Patrick, Neighbours \& Knee, 2004). Terwijl intrinsieke doelen samengaan met een taakoriëntatie, gaan extrinsieke doelen gepaard met een prestatie-oriëntatie (Vansteenkiste, Simons, Lens, Soenens, Matos \& Lacante, 2004; Vansteenkiste, Matos et al., 2007). Extrinsiek georiënteerde mensen deinzen er bovendien niet voor terug om anderen te discrimineren of zelfs te misbruiken om hun doel te bereiken (Duriez, Soenens \& Vansteenkiste, 2007). Het nastreven van extrinsieke doelen werkt dan ook conflicten tussen groepen in de hand (Duriez, Soenens, Vansteenkiste \& De Witte, 2007) en verhindert dat mensen zich goed voelen en goed presteren (Vansteenkiste, Lens et al., 2006). De ZDT neemt aan dat het nastreven van extrinsieke doelen vooral optreedt wanneer de bevrediging van de basisbehoeften belemmerd wordt (Kasser, 2002). Vanuit de Conservation of Resources Theory kan een extrinsieke oriëntatie dan ook begrepen worden als een compensatiestrategie die optreedt wanneer de hulpbronnen bedreigd zijn. Ironisch genoeg belemmert een dergelijke strategie de accumulatie van nieuwe hulpbronnen of behoeftebevrediging (Vansteenkiste, Neyrinck, Niemic, Soenens, De Witte et al., 2007), wat resulteert in een negatieve spiraal.

Sommige auteurs in de A\&G-psychologie maken eveneens een onderscheid tussen intrinsieke en extrinsieke werkwaarden of -doelen (bijv. De Witte, 2000; Feather \& O’Brien, I986; Malka \& Chatman, 2003). Intrinsieke waarden verwijzen hierbij naar de mate waarin werknemers belang hechten aan taakgerelateerde aspecten die inherent verbonden zijn aan het werk (bijv. autonomie en vaardigheidsbenutting). Extrinsieke waarden refereren daarentegen niet aan de inhoud van het werk, maar wel aan het waarderen van arbeidsomstandigheden, -verhoudingen, of -voorwaarden zoals baanzekerheid, sociale steun, goede uren en beloning.

Intrinsiek en extrinsiek hebben in deze definitie van werkwaarden dus een andere betekenis dan in de ZDT. In plaats van het werk, neemt de ZDT immers de inherente groeitendens van mensen en de psychologische basisbehoeften als uitgangspunt voor de opdeling in intrinsieke en extrinsieke doelen, wat resulteert in kleine verschillen in de classificatie van de doelen. Belang hechten aan sociale relaties, bijvoorbeeld, wordt door A\&G-onderzoekers beschouwd als een deelaspect van arbeidsverhoudingen en wordt daarom als extrinsiek gecategoriseerd. Binnen de ZDT wordt dit echter gezien als een intrinsiek doel, omdat het waarderen van sociale relaties in lijn ligt van de basisbehoefte aan verbondenheid. De indeling in intrinsieke en extrinsieke doelen binnen de ZDT is abstracter en overstijgt de verwijzing naar specifieke baankenmerken van de A\&G-indeling. Anders dan het onderscheid in de A\&G- 
psychologie, wordt in de ZDT tot slot de differentiatie tussen intrinsieke en extrinsieke doelen geïntegreerd in een groter theoretisch raamwerk.

In feite sluit de A\&G-differentiatie tussen de waardering van intrinsieke en extrinsieke werkaspecten (bijv. De Witte, 200o) beter aan bij het verschil tussen intrinsieke en extrinsieke motivatie zoals hierboven beschreven. Een rijke arbeidsinhoud kan er immers aan bijdragen dat werknemers hun werk interessant en leuk vinden en dus intrinsiek gemotiveerd raken, terwijl goede arbeidsomstandigheden, -voorwaarden en -verhoudingen extrinsieke motivatie kunnen stimuleren.

In lijn met de ZDT bevestigen verschillende studies dat het nastreven van intrinsieke dan wel extrinsieke doelen van invloed is op persoonlijk en sociaal functioneren (zie Vansteenkiste, Soenens et al., 2008 voor een overzicht). Het nastreven van extrinsieke waarden is op zich niet zo problematisch, maar wordt dat wel wanneer extrinsieke waarden belangrijker worden dan intrinsieke waarden. Daarom wordt in empirisch 328 onderzoek vaak een relatieve score berekend, die aangeeft in welke mate mensen intrinsieke doelen boven extrinsieke doelen verkiezen. Studies die een dergelijke relatieve maat gebruiken, tonen aan dat mensen die intrinsieke doelen verkiezen, beter in hun vel zitten, zich beter ontwikkelen (bijv. Kasser \& Ryan, 1996; Sheldon, Ryan, Deci \& Kasser, 2004), betere prestaties neerzetten, taken langer volhouden (Vansteenkiste, Timmermans, Lens, Soenens \& Van den Broeck, 2008) en minder probleemgedrag vertonen (bijv. Niemiec, Ryan, Deci \&Williams, 2009). Soortgelijke bevindingen werden vastgesteld in de werkcontext. Wanneer werknemers focussen op intrinsieke in plaats van op extrinsieke werkdoelen, ervaren ze meer welzijn, zijn ze minder geneigd de organisatie te verlaten (Vansteenkiste, Neyrinck et al., 2007) en ontwikkelen ze een betere flexibele houding tegenover de arbeidsmarkt (Van den Broeck, Vansteenkiste, Lens \& De Witte, in druk). Zoals verwacht, biedt de bevrediging van de basisbehoeften een verklaring voor deze relaties (Vansteenkiste, Neyrinck et al., 2007).

Dat het nastreven van intrinsieke in plaats van extrinsieke doelen leidt tot beter functioneren, is niet te wijten aan een mogelijk verschil in moeilijkheidsgraad of haalbaarheid van intrinsieke en extrinsieke doelen zoals gesuggereerd zou kunnen worden op basis van de Goal-Setting Theorie. Soortgelijke resultaten worden immers ook gevonden wanneer mensen het 'meer waarschijnlijk vinden' dat ze deze extrinsieke doelen zullen bereiken. Zelfs mensen die zich bekwaam voelen om een extrinsiek doel te bereiken, zitten dus niet beter in hun vel (Kasser \& Ryan, I996). Verder blijkt ook dat het realiseren van extrinsieke doelen niet bijdraagt aan het welzijn van mensen, terwijl dit wel het geval is voor het bereiken van intrinsieke doelen (bijv. Niemiec et al., 2009; Van Hiel \& Vansteenkiste, 2009).

Naast een persoonlijke voorkeur voor bepaalde doelen, kan ook de omgeving in verschillende mate intrinsieke en extrinsieke doelen promoten en zo het functioneren van mensen beïnvloeden: het promoten van intrinsieke doelen leidt bijvoorbeeld tot meer autonome motivatie, welzijn en goede prestaties, terwijl het stimuleren van extrinsieke doelen hier negatief op inwerkt (Vansteenkiste, Simons, Lens, Soenens \& Matos, 2005). Dit geldt voor zowel mensen met een intrinsieke als extrinsieke doeloriëntatie (Vansteenkiste, Timmermans et al., 2008). Het persoon-omgeving-fitperspectief, dat vaak gehanteerd wordt binnen de A\&G-psychologie (Kristof-Brown, Zimmerman \& Johnson, 2005; Warr, 1987), is met andere woorden nog niet bevestigd 
voor de intrinsieke en extrinsieke doelen van de ZDT. In dit fit-perspectief wordt immers verondersteld dat werknemers floreren wanneer hun waarden overeenkomen met de prominente waarden in de organisatie. De resultaten van onderzoek naar intrinsieke en extrinsieke doelen suggereren daarentegen dat de positieve impact van het nastreven en promoten van intrinsieke in plaats van extrinsieke waarden universeel is: wie vooral intrinsiek georiënteerd is, functioneert in elke context beter dan wie vooral extrinsiek georiënteerd is, en het promoten van intrinsieke doelen is steeds beter dan het benadrukken van extrinsieke doelen (Vansteenkiste, Lens et al., 2006).

Samengevat stelt de ZDT dus dat niet alle doelen een positieve impact hebben, maar dat er inhoudelijk een kwalitatief onderscheid gemaakt moet worden. Intrinsieke doelen hebben een positief effect op het functioneren van werknemers, zowel wanneer werknemers ze zelf nastreven als wanneer de omgeving ze aangemoedigt. Extrinsieke doelen leiden eerder af van optimaal functioneren, zeker wanneer ze het nastreven van intrinsieke doelen verdringen.

\section{Conclusie}

In deze bijdrage zijn de basisprincipes en -concepten van de ZDT toegelicht. Deze theorie kan een belangrijke bijdrage leveren aan de positieve $\mathrm{A} \& \mathrm{G}$-psychologie om verschillende redenen. Ten eerste kan zij een solide basis vormen voor de A\&Gpsychologie, omdat zij vertrekt vanuit een positief mensbeeld: mensen zijn actieve op groeigerichte organismen. Daarnaast erkent de ZDT dat de context een positieve dan wel negatieve invloed kan uitoefenen op het functioneren van werknemers. Op die manier laat zij toe om zowel de invloed van de context te onderzoeken op het functioneren van werknemers, als de interactie tussen deze werknemers en hun context. De ZDT is dan ook een omvattende theorie, wat ook tot uiting komt in de kernconcepten en uitkomsten die zij bestudeert.

Terwijl andere theorieën in de A\&G-psychologie gericht zijn op bepaalde aspecten van motivatie, staat de ZDT toe om het 'wat'(de doelen), het 'waarom' (de regulaties) én het onderliggende proces (de behoeften) van motivatie te bestuderen. De kwaliteit van de motivatie staat hierbij steeds centraal: een sterkere motivatie leidt enkel tot meer optimaal functioneren (d.w.z.welzijn, positieve attitudes en coöperatief gedrag) wanneer het gaat om kwalitatief goede motivatie.

De ZDT kan dus een breed scala van fenomenen verklaren (Reeve, 2005). Zij vindt daarbij aansluiting bij verschillende andere geformuleerde positief georiënteerde theorieën, bouwt deze verder uit en integreert ze in een coherent geheel. De ZDT kan daarom onderzoekers inspireren en ondersteunen om de positieve $A \& G$-psychologie op een samenhangende en theoretisch gefundeerde wijze verder uit te bouwen (Deci \& Vansteenkiste, 2004), bestaande onderzoeksvragen te beantwoorden en nieuwe te stellen. Naar de praktijkcontext toe biedt zij bovendien ook handvatten om organisaties en hun HRM-beleid zo te ontwerpen en te implementeren dat ze maximaal motiverend werken (Gagné \& Deci, 2005). 


\section{Praktijkbox}

Wat betekenen de resultaten voor de praktijk?

- De ZDT heeft een duidelijke meerwaarde voor de praktijk, dankzij haar wetenschappelijke onderbouwing, eenvoud, generiek karakter en de inherente verbanden met andere theorieën en concepten uit de AEG-psychologie. Zij biedt een raamwerk om gerichte diagnoses te stellen en interventies te realiseren op verschillende niveaus (d.w.z. individu, team, organisatie), vanuit verschillende rollen (bijv. leidinggevende, HR-verantwoordelijke) en met betrekking tot verschillende motivationele aspecten (d.w.z. regulaties, doelen en behoeften).

- De basisbehoeften zijn drie cruciale hefbomen voor optimaal functioneren. Bij individuele gespreksvoering (bijv. functioneringsgesprek, loopbaanoriëntatie), groepsontwikkeling (bijv. teamvergaderingen, teambuilding) en organisatieveranderingen kan er daarom over gewaakt worden dat elk van de drie behoeften bevredigd wordt.

- De autonome typen van extrinsieke motivatie geven aan hoe werknemers meer extrinsiek gemotiveerd kunnen worden zonder dat hun intrinsieke motivatie ondermijnd wordt. Dit kan met name door het belang te benadrukken van weinig interessante taken.

- Het onderscheid tussen intrinsieke en extrinsieke waarden nodigt uit om financieel succes en status ondergeschikt te maken aan zelfontwikkeling en het leveren van een bijdrage aan de samenleving bij het formuleren van doelen voor (potentiële) werknemers en de organisatie als geheel (bijv. missie en waarden).

\section{Noot}

1. De bijdrage van de eerste auteur werd gefinancierd door het Fonds voor

Wetenschappelijk Onderzoek Vlaanderen (FWO-Vlaanderen). We willen Ilona van

Beek bedanken voor haar suggesties bij dit manscript.

\section{Literatuur}

Assor, A., Vansteenkiste, M. \& Kaplan, A. (2009). Identified and introjection approach and introjection avoidance motivations in school and in sport: The limited benefits of selfworth strivings. Journal of Educational Psychology, IOI, 482-497.

Baard, P., Deci, E.L \& Ryan, R.M. (2004). Intrinsic need satisfaction: A motivational basis of performance and well-being in two work settings. Journal of Applied Social Psychology, 34, $2045^{-2068 . ~}$

Bandura, A. (1997). Self-efficacy: The exercise of control. New York: W.H. Freeman.

Baumeister, R. \& Leary, M. (I995). The need to belong. Desire for interpersonal attachments as a fundamental human motivation. Psychological Bulletin, II7, 497-529.

Bono J.E. \& Judge, T. A. (2003). Self-concordance at work: Toward understanding the motivational effects of transformational leaders. Academy of Management Journal, 46, 554-57I.

De Witte, H. (2000), Houdingen tegenover arbeid in België op de drempel van de eenentwintigste eeuw. In K. Dobbelaere, M. Elchardus, J. Kerkhofs, L. Voyé \& B. Bawin-Legros (Red.), Verloren zekerheid. De Belgen en hun waarden, overtuigingen en houdingen (p. 77-II6). Tielt: Lannoo.

DeCharms, R. (1968). Personal causation: The internal affective determinants of behavior. New York: Academic Press. 
Deci, E.L. (1971). Effects of externally mediated rewards on intrinsic motivation. Journal of Personality and Social Psychology, I8, 105- II5.

Deci, E.L., Connell, J.P. \& Ryan, R.M. (1989). Self-determination in a work organization. Journal of Applied Psychology, 74, 580-590.

Deci, E.L., Koestner, R. \& Ryan, R.M., (I999). A meta-analytic review of experiments examining the effects of extrinsic rewards on intrinsic motivation. Psychological Bulletin, I25, 627-668.

Deci, E.L. \& Ryan, R.M. (2000). The 'what' and 'why' of goal pursuits: Human needs and the self-determination of behavior. Psychological Inquiry, II, 319-338.

Deci, E.L., Ryan, R.M., Gagné, M., Leone, D.R., Usunov, J. \& Kornazheva, B.P. (200I). Need satisfaction, motivation, and well-being in the work organizations of a former Eastern Bloc country. Personality and Social Psychology Bulletin, 27, 930-942.

Deci, E.L. \& Vansteenkiste, M. (2004). Self-determination theory and basic need satisfaction: Understanding human development in positive psychology. Richerche di Psicologia, 27, 23-40.

Duriez, B., Soenens, B. \& Vansteenkiste, M. (2007). In search of the antecedents of adolescent authoritarianism: The relative contribution of parental goal promotion and parenting style dimensions. European Journal of Personality, 2I, 507-527.

Duriez, B., Vansteenkiste, M., Soenens, B. \& De Witte, H. (2007). The social costs of extrinsic relative to intrinsic goal pursuits: Their relation with social dominance and racial and ethnic prejudice. Journal of Personality, $75,757^{-7} 782$.

Elliot, A.J., McGregor, H.A. (200I). A 2 x 2 achievement goal framework. Journal of Personality and Social Psychology, 80, 50I-5I9.

Feather, N. (I992). Values, valences, expectations, and actions. Journal of Social Issues, 48, 109I24.

Feather, N. \& O'Brien, G. (I986). A longitudinal analysis of the effects of different patterns of employment and unemployment on school-leavers. British Journal of Psychology, 77, 459-479.

Fernet, C., Guay, F. \& Senécal, C. (2004). Adjusting to job demands: The role of work selfdetermination and job control in predicting burnout. Journal of Vocational Behaviour, 65, 39-56.

Fernet, C., Sen, C., Guay, F., Marsh, H. \& Dowson, M., (2008). The work tasks motivation scale for teachers (WTMST). Journal of Career assessment, I6, 256-279.

Frey, B.S. \& Osterloh, M. (2005). Yes, managers should be paid like bureaucrats. Journal of Management Inquiry, I4, 96-III.

Gagné, M. (2003). The role of autonomy support and autonomy orientation in prosocial behavior engagement. Motivation and Emotion, 27, 199-223.

Gagné, M. \& Deci, E.L. (2005). Self-determination theory and work motivation. Journal of Organizational Behaviour, 26, 33I-362.

Gagné, M. \& Forest, J. (2008). The study of compensation systems through the lens of selfdetermination theory: Reconciling 35 years of debate. Canadian Psychology, 49, $225^{-232 .}$

Gagné, M., Koestner, R. \& Zuckerman, M. (2000). Facilitating acceptance of organizational change: The importance of self-determination. Journal of Applied Social Psychology, zo, I843-I852.

Gagné, M., Senécal, C.B. \& Koestner, R. (1997). Proximal job characteristics, feelings of empowerment, and intrinsic motivation: A multidimensional model. Journal of Applied Social Psychology, 27, I222-I240.

Guay, F., Senécal, C., Gauthier, L. \& Fernet, C. (2003). Predicting career indecision: A selfdetermination theory perspective. Journal of Counseling Psychology, 50, I65-177.

Hackman, J. \& Oldham, G. (I976). Motivation through the design of work: Test of a theory. Organizational Behavior and Human Performance, I6, $250-279$.

Herzberg, F. (1968). Work and the nature of man, London: Crosby.

Higgins, E.T. (1997). Beyond pleasure and pain. American Psychologist, 52, I280-1300.

Higgins, E.T. (2000). Making a good decision: Value from fit. American Psychologist, 55, I2I7-I23O. 
Hobfoll, S.E. (1989). Conservation of Resources. A new attempt at conceptualizing stress. American Psychologist, 44, 513-524.

Hobfoll, S. (2002). Social and psychological resources and adaptation. Review of General Psychology, 6, 307-324.

Ilardi, B., Leone, D., Kasser, T. \& Ryan, R. (1993). Employee and supervisor ratings of motivation: Main effects and discrepancies associated with job satisfaction and adjustment in a factory setting. Journal of Applied Social Psychology, 23, I789-I805.

Jahoda, M. (1982). Employment and unemployment. A social-psychological analysis. Cambridge: University Press.

Judge, T.A., Bono, J.E., Erez, A. \& Locke, E.A. (2005). Core self-evaluations and job and life satisfaction: The role of self-concordance and goal attainment. Journal of Applied Psychology, 90, 257-268.

Karasek, R. (I979). Job demands, job decision latitude, and mental strain - Implications for job redesign. Administrative Science Quarterly, 24, 285-308.

Kasser, T. (2002). The high price of materialism. London: MIT Press.

Kasser, T. \& Ryan, R. (I996). Further examining the American dream: Differential correlates of intrinsic and extrinsic goals. Personality and Social Psychology Bulletin, 22, $280-287$.

Kasser, T., Davey, J. \& Ryan, R.M. (1992). Motivation and employee-supervisor discrepancies in a psychiatric vocational rehabilitation setting. Rebabilitation Psychology, 37, $175-187$.

Kristof-Brown, A., Zimmerman, R. \& Johnson, E. (2005). Consequences of individuals' fit at work: A meta-analysis of person-job, person-organization, person-group, and personsupervisor fit. Personnel Psychology, 58, 285-342.

Lam, C.F. \& Gurland, S.T. (2008). Self-determined work motivation predicts job outcomes, but what predicts self-determined work motivation? Journal of Research in Personalilty, 42, IIO9-III5.

Latham, G.P. \& Locke, E.A. (2006). Enhancing the benefits and overcoming the pitfalls of goal setting. Organizational Dynamics, 35, 332-340.

LePine, J.A., Piccolo, R.F., Jackson, C.L., Mathieu, J.E. \& Saul, J.R. (2008). A metaanalysis of teamwork processes: Tests of a multidimensional model and relationships with team effectiveness criteria. Personnel Psychology, 6I, 273-307.

Locke, E.A. \& Latham, G.P. (I990). A theory of goal setting and task performance. Englewood Cliffs, NJ, Prentice Hall.

Luthans, F. \& Youssef, C.M. (2004). Human, social, and now positive psychological capital management: Investing in people for competitive advantage. Organizational Dynamics, 33,I43-I6o.

Luyten, H. \& Lens, W., (198I). The effect of earlier experience and reward contingencies on intrinsic motivation. Motivation and Emotion, 5, 25-36.

Lynch, M., Plant, R. \& Ryan, R. (2005). Psychological needs and threat to safety: Implications for staff and patients in a psychiatric hospital for youth. Professional Psychology - Research and Practice, 36, 415-425.

Malka, A. \& Chatman, J.A. (2003). Intrinsic and extrinsic work orientations as moderators of the effect of annual income on subjective well-being: A longitudinal study. Personality and Social Psychology Bulletin, 29, 737-746.

Maslow, A. (I943). A theory of human motivation. Psychological Review, 50, 370-396.

McClelland, D.C. (1965). Achievement and entrepreneurship: A longitudinal study. Journal of Personality and Social Psychology, I4, 389-392.

McGregor, D., (1960). The Human Side of Enterprise. New York: McGraw-Hill.

Meyer, J.P., Becker, T.E. \& Vandenberghe, C. (2004). Employee commitment and motivation: a conceptual analysis and integrative model. Journal of Applied Psychology, 89, 99I-1007.

Milette, V. \& Gagné, M. (2008). Designing volunteers' tasks to maximize motivation, satisfaction and performance: The impact of job characteristics on the outcomes of volunteer involvement. Motivation and Emotion, 32, II-22. 
Mouratadis, M., Vansteenkiste, M., Lens, W., \& Sideridis, G. (2008). The motivating role of positive feedback in sport and physical education: Evidence for a motivational model. Journal of Sport E' Exercise Psychology, 30, 240-268.

Niemiec, C.P., Ryan, R.M., Deci, E.L., \& Williams, G.C. (2009). Aspiring to physical health: The role of aspirations for physical health in facilitating long-term tobacco abstinence. Patient Education and Counseling, 74, 250-257.

Parker, S.L., Jimmieson, N.L., Amiot, C.E. (in press). Self-determination as a moderator of demands and control: Implications for employee strain and engagement. Journal of Vocational Behavior.

Patrick, H., Neighbors, C.T. \& Knee, C.R. (2004). Appearance-related social comparisons: The role of contingent self-esteem and self-perceptions of attractiveness. Personality and Social Psychology Bulletin, 30, 50I-514.

Pinder, C. (2008). Work motivation in organizational behavior (2nd ed.). New York: Psychology press.

Reeve, J. (2005). Understanding motivation and emotion (4th ed.). Hoboken, NJ: Wiley.

Reis, H., Sheldon, K., Gable, S., Roscoe, J. \& Ryan, R. (2000). Daily well-being: The role of autonomy, competence, and relatedness. Personality and Social Psychology Bulletin, 26, 4I 9 - 435 .

Richer, S.F., Blanchard, C. \& Vallerand, R.J. (2002). A motivational model of work turnover. Journal of Applied Social Psychology, 32, 2089-2II3.

Ryan, R.M. \& Connell, J.P. (1989). Perceived locus of causality and internalization: Examining reasons for acting in two domains. Journal of Personality and Social Psychology, 57, 749-76r.

Rynes, S.L., Gerhart, B. \& Parks, L. (2005). Personnel psychology: Performance evaluation and pay for performance. Annual Review of Psychology, 56, 571-60o.

Schaufeli, W.B. (2004). De psychologie van arbeid en gezondheid: Verleden, heden en toekomst. Gedrag \& Organisatie, $17,326-340$.

Schaufeli, W.B. \& Bakker, A.B. (200I). Werk en welbevinding. Naar een positieve benadering in de arbeids- en gezondheidspsychologie. Gedrag \& Organisatie, 5, 229-253.

Seligman, M. \& Csikszentmihalyi, M. (2000). Positive psychology - An introduction. American Psychologist, 55, 5-I4.

Senécal, C. \& Guay, F. (200I). Procrastination in job-seeking: An analysis of motivational processes and feelings of hopelessness. Journal of Social Behavior and Personality, 15, 267282.

Shapiro, S.P. (2005). Agency theory. Annual Review of Sociology, 3I, $263-284$.

Sheldon, K., Ryan, R., Deci, E. \& Kasser, T. (2004). The independent effects of goal contents and motives on well-being: It's both what you pursue and why you pursue it. Personality and Social Psychology Bulletin, 30, 475-486.

Sheldon, K., Turban, D., Brown, K., Barrick, M., \& Judge, T. (2003). Applying SelfDetermination Theory to organizational research. Research in Personnel and Human Resources Management, 22, 357-393.

Skinner, B.F. (1974). About behaviorism. New York: Knopf.

Steers, R.M., Mowday, R.T. \& Shapiro, D.T. (2004). The future of work motivation theory. Academy of Management Review, 29, 379-287.

Van den Broeck, A., Vansteenkiste, M. \& De Witte, H. (2008). Self-determination theory: A theoretical and empirical overview in occupational health psychology. In J. Houdmont \& S. Leka (Eds.), Occupational health psychology: European perspectives on research, education, and practice (Vol. 3, pp. 63-88). Nottingham: Nottingham University Press.

Van den Broeck, A., Vansteenkiste, M., De Witte H. \& Lens, W. (2008). Explaining the relationships between job characteristics, burnout and engagement: The role of basic psychological need satisfaction. Work E' Stress, 22, 277-294.

Van den Broeck, A., Vansteenkiste, M., Lens, W., \& De Witte, H. (in press). Unemployed individuals' work values and job flexibility: An explanation from expectancy-value theory and self-determination theory. Applied Psychology: An International Review. 
Van Hiel, A. \& Vansteenkiste, M. (2009). Ambitions fullfilled? The effects of intrinsic and extrinsic goal attainment on older adults' ego-integrity and death attitudes. International Journal of Aging and Human Development, 68, 27-51.

Vansteenkiste, M., Lens, W. \& Deci, E.L. (2006). Intrinsic versus extrinsic goal contents in self-determination theory: Another look at the quality of academic motivation. Educational Psychologist, 4I, I9-3I.

Vansteenkiste, M., Lens, W., De Witte, H. \& Feather, N. (2005). Understanding unemployed people's job-search behaviour, unemployment experience and well-being: A comparison of expectancy-value theory and self-determination theory. British Journal of Social Psychology, 44, I-20.

Vansteenkiste, M., Lens, W., Dewitte, S., De Witte, H. \& Deci, E.L. (2004). The 'why' and 'why not' of job-search behaviour: Their relation to searching, unemployment experience, and well-being. European Journal of Social Psychology, 34, 345-363.

Vansteenkiste, M., Matos, L., Lens, W. \& Soenens, B. (2007). Understanding the impact of intrinsic versus extrinsic goal framing on exercise performance: The conflicting role of task and ego involvement. Psychology of Sport and Exercise, 8, 771-794.

334 Vansteenkiste, M., Neyrinck, B., Niemic, C., Soenens, B., De Witte, H. \& Van den Broeck, A. (2007). Examining the relations among extrinsic versus intrinsic work value orientations, basic need satisfaction, and job experience: A self-determination theory approach. Journal of Occupational and Organizational Psychology, 80, 251-277.

Vansteenkiste, M., Ryan, R.M. \& Deci, E.L. (2008). Self-determination theory and the explanatory role of psychological needs in human well-being. In L. Bruni, F. Comim \& M. Pugno (Eds.), Capabilities and happiness (pp. 187-223). Oxford: Oxford University Press.

Vansteenkiste, M., Simons, J., Lens, W., Soenens, B. \& Matos, L. (2005). Examining the impact of extrinsic versus intrinsic goal framing and internally controlling versus autonomy-supportive communication style upon early adolescents' academic achievement. Child Development, 76, 483-501.

Vansteenkiste, M., Simons, J., Lens, W., Soenens, B., Matos, L. \& Lacante, M. (2004). Less is sometimes more: Goal content matters. Journal of Educational Psychology, 4, 755-764.

Vansteenkiste, M., Soenens, B. \& Duriez, B. (2008). Presenting a positive alternative to materialistic strivings and the thin-ideal: Understanding the effects of extrinsic relative to intrinsic goal pursuits. In Lopez, S.J. (Ed.), Positive psychology: Exploring the best in people (Vol. 4, pp. 57-86). Westport, CT: Greenwood Publishing Company.

Vansteenkiste, M., Timmermans, T., Lens, W., Soenens, B. \& Van den Broeck, A. (2008). Does extrinsic goal framing enhance extrinsic goal oriented individuals' learning and performance? An experimental test of the match-perspective vs. self-determination theory. Journal of Educational Psychology, I00, 387-397.

Viswesvaran, C., Sanchez, J.I. \& Fisher, J. (1999). The role of social support in the process of work stress: A meta-analysis. Journal of Vocational Behavior, 54, 314-334.

Vroom, V. (1964). Work and motivation. New York: Wiley.

Warr, P. (1987). Work, unemployment, and mental health. Oxford: Clarendon.

White, R. (1959). Motivation reconsidered: The concept of competence. Psychological Review, 66, 279-333.

Winterbottom, M.R. (1959). The relation of need for achievement to learning experiences in independence and mastery. In J.W. Atkinson (Ed.), Motives in fantasy, action and society (pp. 453-478). Princeton: Van Nostrand.

Wright, S.L., Burt, C.D., \& Strongman, K.T. (2006). Loneliness in the workplace: Construct definition and scale development. New Zealand Journal of Psychology, 35, 59-68.

\section{Self-Determination Theory: about the quality of work motivation}

A. van den Broeck, H. de Witte, M. Vansteenkiste, W. Lens \& M. Andriessen, Gedrag \& Organisatie, volume 22, November 2009, nr. 4, pp. 316-334. 
The call for a positive psychology has stimulated research on optimal functioning both in general and in the context of work. The Self-Determination Theory (SDT) might provide a useful framework in which positive work and organisational psychology can be grounded and might stimulate theoretical developments in this field. Starting from a positive concept of man, ZDT reflects upon different aspects of motivation. In the current paper, we describe ZDT and touch upon its relationships with other, and perhaps more well-known, work and organisational theories. We furthermore discuss the empirical evidence in favour of ZDT and illustrate its practical relevance in the context of work.

Key words: Self-Determination Theory, positive psychology, work motivation 